Vol. 3: 06-14, May 2017

ISSN: 2392-4535 (Print), 2392-4543 (Online)

DOI: http://dx.doi.org/10.3126/jnarc.v3i1.17269

\title{
Yield Evaluation of Nutrient-rich Potato Clones in High Hill of Nepal
}

\author{
Binod Prasad Luitel ${ }^{1 @}$, Bhim Bahadur Khatri ${ }^{1}$, Laxmi Lama ${ }^{2}$, Rajeev Dhakal ${ }^{2}$, Kamal Khadka $^{2}$, Duryodhan Choudhary ${ }^{1}$, Sushma Arya ${ }^{3}$, \\ Merideth Bonierbale ${ }^{4}$ and Mohinder Singh Kadian ${ }^{3}$
}

${ }^{1}$ National Potato Research Program (NPRP), Khumaltar, Lalitpur. @: binodsan@yahoo.com, BBK<bhim_khatri@hotmail.com>, LL<laxmi.titung@gmail.com>, RD <rdhakal@libird.org>, KK<kkhadka@libird.org>, DC<duryodhanchd@gmail.com>, SA<s.arya@cgiari.org>, MB <m.bonierbale@cgiar.org> and MSK<m.kadian@cgiar.org >

${ }^{2}$ Local Initiatives for Biodiversity, Research and Development (LI-BIRD), Kaski, Nepal

${ }^{3}$ International Potato Center, South West and Central Asia Region, New Delhi, India

${ }^{4}$ International Potato Center, Lima, Peru

Received May 2016, Revised January 2017, Accepted April 2017, Published May 2017

Scientific Editors: Jiban Shrestha, Ram Bahadur KC

Copyright @2017 NARC. Permits unrestricted use, distribution and reproduction in any medium provided the original work is properly cited

\begin{abstract}
A study was conducted to evaluate the yield of nutrient-rich potato clones in high-hill districts: Dolakha and Jumla of Nepal during the years 2013 and 2014, respectively. Fourteen potato clones were tested as on-station and on-farm experiments at both districts, and those fourteen clones were compared to 'Lady Rosita' and 'Jumli Local' respectively as the check varieties in the first year experiment, 2013. Eight promising clones were selected from the first year experiment, and were evaluated and compared with same local varieties in the consecutive year, 2014. Two clones namely; CIP 395112.32 (19.3 tha $\left.{ }^{-1}\right)$ and CIP 393073.179 (17.8 tha $\left.{ }^{-1}\right)$ exhibited superior marketable tuber yield than that of 'Lady Rosita' $\left(14.2\right.$ tha $\left.^{-1}\right)$ in Dolakha and five CIP clones namely; $395112.32\left(25.5\right.$ tha $\left.^{-1}\right), 393073.179\left(22.5\right.$ tha $\left.^{-1}\right)$, $394611.112\left(20.9\right.$ tha $\left.^{-1}\right), 390478.9\left(19.9\right.$ tha $\left.^{-1}\right)$ and $395017.229\left(17.0\right.$ tha $\left.^{-1}\right)$ showed higher marketable tuber yield than 'Jumli Local'(14.5 tha $^{-1}$ ). Based on two years' phenotypic and tuber yield result, clones CIP 395112.32 and CIP 393073.179 are recommended to potato growers at high hills of Nepal for commercial cultivation.
\end{abstract}

Keywords: Clones, Nutrient-rich, On-farm, On-station, Phenotypic, Yield

सारांश

बढी उत्पादकत्व भएका आलुका जातहरुको नेपालको दोलखा र जुम्ला उच्च पहाडी जिल्लाहरुमा पोषणयुक्त आलुका जातहरुको उत्पादन मुल्यांकन गर्न र सिफारिश गर्ने उद्वेश्य ले क्रमशः सन् २०१३ र सन् २०१४ मा एक अध्ययन गरिएको थियो। पहिलो बर्ष सन् २०१३ को परिक्षणमा चौध आलुका जातहरु दुवै जिल्लाहरुमा अनुसन्धान केन्द्र र कृषकको खेतवारीमा परिक्षण गरिएको थियो र उक्त चौध आलुका जातहरु कमश: लेडी रोजीटा र जुम्ली स्थानीय चेकजातहरुसँग तुलना गरियो भने पहिलो वर्षको परिक्षणवाट छानिएका आठ प्रोमीजिड जातहरु सन् २०१४ मा सोही स्थानीय जातहरुसँग मुल्यांकन एंव तुलना गरियो। दुई जातहरुले सि.आई.पि. ३९५११२.३२ (१९.३ टन प्रति हेक्टर) र सि.आइ.पि ३९३०७३.१७९ (१७.५ टन प्रति हेक्टर) ले दोलखामा लेडी रोजीटा (१४.२ टन प्रति हेक्टर) को भन्दा उत्कृष्ट बजार योग्य दानाको उत्पादन देखायो भने, पांच सि.आई.पि. जातहरु ३९५११२.३२ (२४.४ टन प्रति हेक्टर), ३९३०७३.१७९ (२२.४ टन प्रति हेक्टर), ३९४६११.११२ (२०.९ टन प्रति हेक्टर), ३९०४७६.९ (१९.९ टन प्रति हेक्टर) र ३९५०१७.२२९ (१७.० टन प्रति हेक्टर) ले जुम्ली स्थानीय (१४.५ टन प्रति हेक्टर) भन्दा उच्च बजार योग्य दानाको उत्पादन देखायो। दुई वर्षको फिनोटाइप र दाना उत्पादन परिणामको आधारमा सि.आई.पि. ३९५११२.३२ र सि.आई.पि. ३९३०७३.१७९ जातहरुलाई नेपालको उच्च पहाडमा आलु उत्पादकहरुलाई व्यावसायिक खेतीको लागि सिफारिस गरिएको छ।

\section{INTRODUCTION}

Potato is an important crop for food security in the high-hills of Nepal contributing substantially to the livelihood of resourcepoor farmers in mountains (NPRP 2014). Despite its huge importance, its productivity in mountain districts is estimated to be around 10.1 t ha $\mathrm{th}^{-1}$ which is lower than the national average of $13.6 \mathrm{t} \mathrm{ha}^{-1}$ (ABSPD 2013). Traditional potato varieties those predominantly grown in high-hills are low-yielding with poor nutritional qualities (NPRP 2014). In order to feed the galloping population and fulfill high nutrition requirement of the people, there is much mu need to select for providing high yielding and nutrition-rich improved potato varieties in high hills of Nepal. 
Stunting and underweight caused by malnutrition are severe problems in children of mountain regions (NPC 2010). Potato is a potential crop to alleviate such problems owing to its important source of vitamins and minerals. International Potato Center (CIP), Peru has developed nutrition-rich potato varieties through complement resistance breeding since 2009. Through dietary diversification of the people, CIP developed bio-fortified varieties containing high content of zinc and iron which can play vital role to reduce hunger of mountain regions and can fulfill the micronutrient requirement thereby helping to reduce malnutrition of mountain regions (www.harvestplus.org). Therefore, genotypic evaluation in stress-prone mountain regions can be the best approach to select location-specific, high yielding and nutrient-rich varieties.

National Potato Research Program (NPRP) has released ten potato varieties from CIP genetic materials and recommended for commercial cultivation at different agro-ecological regions of Nepal (NPRP 2014). But these varieties are not nutrient-rich and unable to address the present needs of consumers. In general, the released varieties 'IPY-8' and 'Khumal Laxmi' yielded 25 to $27 \mathrm{t} \mathrm{ha}^{-1}$ and 24 to $28 \mathrm{tha}^{-1}$, respectively on hills and terai regions of Nepal (Khatri et al 2010). Similarly, the average yield of 'Khumal Ujjwol' and 'Khumal Upahar' were reported to be 25 tha $^{-1}$ and $24 \mathrm{t} \mathrm{ha}^{-1}$, respectively (Khatri et al 2015). Variety development is a continuous process to replace obsolete varieties by new and high yielding ones. Variety testing and selection scheme of NPRP involve a series of on-station and on-farm experiments in Nepal. But resource-poor farmers from high hill have less access to the most appropriate cultivars under the existing system of variety testing and identification. Genotypes performed well in on-station trials may yield lower or fail completely in farmers' fields, when the plant encounters more challenges. On-farm trials are important to speed up the variety development process and enhance the adoption of new varieties in farm communities (Romney et al 2003, Assefa et al 2005). Therefore, to evaluate and select high yielding nutrient-rich potato varieties suitable for targeted environments, various on-station and on-farm experiments were undertaken simultaneously with CIP clones.

\section{MATERIALS AND METHODS}

\section{Experimental materials and location}

In-vitro plantlets of 14 germplasm of CIP-bred nutrient-rich potato clones mainly 395112.32 (high vitamin C), 393536.13 (high Zn) 392740.4 (high Zn and vitamin C), 393073.179 (high Zn and vitamin C), 399092.116 (high Fe) 393382.44 (high $\mathrm{Zn}$ and vitamin C), 394611.112 (high vitamin C), 390478.9 (high Fe) 393617.1 (high vitamin C) 399078.11 (high Fe, Zn and vitamin C), 395017.242 (high Fe) 395017.229 (high Fe), 394613.139 (high vitamin C), 399067.22 (high Fe) (CIP, 2014) were introduced to NPRP and multiplied at tissue culture laboratory in 2011. Pre-basic seeds (PBS) of each clone were produced in screen-house in the year 2011 and seed tubers were further multiplied at Hattiban Research Farm, Khumaltar in 2012 to fulfill the requirement of planting materials. Seed tubers were stored in cold-store for four months after harvesting and then, prepared for experiments in 2013.

Nucleus Seed Potato Center (NSPC), Nigaley, Sindhupalchok (2740'44" N and 85 55'56" E, 2,550 masl) and farmers' fields of Sindhupalchok and Dolakha districts were selected as the experimental sites of central hills and Agriculture Research Station (ARS), Rajikot, Jumla ( $28^{\circ} 28^{\prime} \mathrm{N}, 81^{\circ} 28^{\prime}$ E, 2,330 masl) and farmers' fields from Patmara and Talium villages were selected as research sites from western hills in Jumla district. Experiments in Dolakha and Jumla were carried out by two independent institutions, respectively, NPRP, Khumaltar for the first and Local Initiatives for Biodiversity Research and Development (LI-BIRD) for the latter. 'Lady Rosita' a very popular farmers' variety in Dolakha and 'Jumli Local' in Jumla were used as the check variety in both on-station and on-farm trials.

\section{Experimental procedure}

Experiment I: Two experiments were conducted simultaneously at each site; Dolakha and Jumla in 2013. In Dolakha, onstation experiment consisted of fourteen clones and a check variety 'Lady Rosita'. The clones were arranged in randomized complete block design (RCBD) with three replications. Well-sprouted tubers were planted at the spacing of $60 \mathrm{~cm} \mathrm{x} 25 \mathrm{~cm}$ having the plot size of $5.4 \mathrm{~m}^{2}$ and trial was planted in February 7, 2013 at NSPC, Nigaley. Fertilizers and farmyard manure (FYM) were applied at the rate of 100:100:60 $\mathrm{NP}_{2} \mathrm{O}_{5} \mathrm{~K}_{2} \mathrm{O} \mathrm{kgha}^{-1}$ and $20 \mathrm{tha}^{-1}$, respectively as per the recommendations. All the fertilizers and FYM were used as basal dose at the time of planting.

A set (fourteen clones along with a local check) of clones were planted in four farmers' field, which was considered onereplica of the experiment and the plot size was maintained at $2.4 \mathrm{~m}^{2}$. Fertilizers used were the same as on-station experiments and agronomic practices were also followed as per the recommendation of NPRP (NPRP 2014). On-station trial was planted 
in Agriculture Research Station (ARS), Rajikot in April 14, 2013 following the same protocol of on-station and on-farm experiments of Dolakha. Cultural practices at both sites were followed as per the recommendations of NPRP.

Experiment II: Eight CIP clones (395112.32, 395017.229, 394611.112, 395017.242, 393617.1, 399078.11, 393073.179 and 394613.139) were selected from first year and compared to local check 'Lady Rosita' in both on-station and on-farm experiments in Dolakha. On-station trial was planted on February 10, 2014 and trial was arranged in RCBD with three replications. Plot size, spacing and all other intercultural practices were used as same as in experiment I. On-farm trials consisted of six farmers and a set (eight clones and a check variety 'Lady Rosita') of potato varieties were planted at each six farmers' field. The plot size was $5.4 \mathrm{~m}^{2}$ for each genotype and spacing and fertilization were similar as experiment I. In Jumla, eight clones were similar to Dolakha (except CIP 394613.139) but CIP 390478.9 (Tacna) and local check 'Jumli Local' were used instead of CIP 394613.139 and 'Lady Rosita'. For Jumla, the methodologies adopted were the same as in Dolakha experiment II. On-station and on-farm trials were planted on April 20, 2014 in Jumla and cultural practices were adopted as per the methods followed in experiment I.

Observation and statistical analysis: Experiments I and II in both sites were harvested in August, 2013 and 2014, respectively. Total numbers of tuber produced plant ${ }^{-1}$ at both experiments were recorded. The tuber size ranging from 25-50 $\mathrm{g}$ to $>50 \mathrm{~g}$ in size was categorized as marketable tuber according to Khatri and Luitel (2014). Marketable tuber weight plant ${ }^{-1}$ and marketable tuber yield was calculated using methods described by De Haan et al (2014). Maturity period and tuber characters (color, flesh color, shape and eye depth) of clones were assessed in experiment using protocol developed by Khatri and Luitel (2014). The quantitative data recorded in experiment I and experiment II were analyzed using GenStat Discovery Edition. Least Significant Difference (LSD) values at 0.05 level of probability for each variable are presented. Average marketable tuber yield of potato clones in experiment I and II at both research sites were computed using Microsoft Excel (version 10.0; Microsoft, Redmond, WA, USA).

\section{RESULTS}

\section{Yield evaluation in experiment I}

The result of total tuber plant ${ }^{-1}$, marketable tuber weight plant $^{-1}$ and marketable yield of tested clones in on-station trials at both locations are presented in Table 1. The clone CIP 395017.229 had the highest (12) total tuber number plant ${ }^{-1}$ in Dolakha followed by CIP 394611.112 (11) and CIP 399067.22 (11), respectively but values were not significantly (P $\leq 0.01)$ different. In Jumla, total tuber number plant $^{-1}$ produced the highest (6) by the clones CIP 392740.4, CIP 393382.44, CIP 394611.112, CIP395017.229 and 'Jumli Local'. Average tuber number plant $^{-1}$ was highest (9) in CIP 394611.12 and CIP 395017.229 (9). Marketable tuber weight plant $^{-1}$ was highly significant $(\mathrm{P} \leq 0.01)$ among the clones tested in both the locations. Average marketable tuber weight plant ${ }^{-1}$ was produced the highest in CIP 395112.32 (308) followed by CIP 395017.229 (247) and CIP 393073.179 (235). Highly significant $(\mathrm{P} \leq 0.01)$ difference was observed in marketable yield among all the clones in both the locations. Clone CIP 395112.32 yielded the highest $\left(20.5 \mathrm{t} \mathrm{ha}^{-1}\right)$ over the locations followed by CIP $395017.229\left(16.6 \mathrm{t} \mathrm{ha}^{-1}\right)$ and CIP $393073.179\left(15.7 \mathrm{t} \mathrm{ha}^{-1}\right)$.

Table 1. Total tuber number, marketable tuber weight and yield of potato clones in on-station experiments in Dolakha and Jumla, 2013

\begin{tabular}{|c|c|c|c|c|c|c|c|c|c|}
\hline \multirow[t]{2}{*}{ Potato clones } & \multicolumn{2}{|c|}{$\begin{array}{l}\text { Total tuber } \\
\text { plant }^{-1} \text { (no.) }\end{array}$} & \multirow[t]{2}{*}{ Mean } & \multicolumn{2}{|c|}{$\begin{array}{l}\text { Marketable tuber } \\
\text { weight plant }^{-1}(\mathrm{~g})\end{array}$} & \multirow[t]{2}{*}{ Mean } & \multicolumn{2}{|c|}{$\begin{array}{l}\text { Marketable tuber } \\
\text { yield }\left(\mathrm{t} \mathrm{ha}^{-1}\right)\end{array}$} & \multirow[t]{2}{*}{ Mean } \\
\hline & Dolakha & Jumla & & Dolakha & Jumla & & Dolakha & Jumla & \\
\hline CIP 395112.32 & 8 & 5 & 7 & 367 & 250 & 308 & 24.4 & 16.6 & 20.5 \\
\hline CIP 393536.13 & 3 & 4 & 4 & 93 & 80 & 87 & 6.2 & 5.3 & 5.7 \\
\hline CIP 392740.4 & 6 & 6 & 6 & 160 & 120 & 140 & 10.6 & 7.9 & 9.3 \\
\hline CIP 393073.179 & 6 & 4 & 5 & 263 & 207 & 235 & 17.6 & 13.7 & 15.7 \\
\hline CIP 399092.116 & 6 & 4 & 5 & 50 & 37 & 43 & 3.3 & 2.4 & 2.8 \\
\hline CIP 393382.44 & 5 & 6 & 6 & 113 & 127 & 120 & 7.4 & 8.3 & 7.9 \\
\hline CIP 394611.112 & 11 & 6 & 9 & 157 & 217 & 187 & 10.5 & 14.2 & 12.4 \\
\hline CIP 390478.9 & 3 & 4 & 4 & 30 & 157 & 93 & 1.9 & 10.3 & 6.1 \\
\hline CIP 393617.1 & 8 & 5 & 7 & 120 & 60 & 90 & 8.1 & 3.9 & 6.1 \\
\hline CIP 399078.11 & 9 & 4 & 7 & 133 & 100 & 117 & 8.7 & 6.7 & 7.7 \\
\hline CIP 395017.242 & 4 & 5 & 5 & 157 & 170 & 163 & 10.4 & 11.1 & 10.7 \\
\hline
\end{tabular}


Yield evaluation of nutrient-rich potato clones by BP Luitel et al

\begin{tabular}{|c|c|c|c|c|c|c|c|c|c|}
\hline \multirow[t]{2}{*}{ Potato clones } & \multicolumn{2}{|c|}{$\begin{array}{l}\text { Total tuber } \\
\text { plant }^{-1} \text { (no.) }\end{array}$} & \multirow[t]{2}{*}{ Mean } & \multicolumn{2}{|c|}{$\begin{array}{l}\text { Marketable tuber } \\
\text { weight plant }^{-1}(\mathrm{~g})\end{array}$} & \multirow[t]{2}{*}{ Mean } & \multicolumn{2}{|c|}{$\begin{array}{l}\text { Marketable tuber } \\
\text { yield }\left(t h^{-1}\right)\end{array}$} & \multirow[t]{2}{*}{ Mean } \\
\hline & Dolakha & Jumla & & Dolakha & Jumla & & Dolakha & Jumla & \\
\hline CIP 395017.229 & 12 & 6 & 9 & 313 & 180 & 247 & 20.9 & 12.2 & 16.6 \\
\hline CIP 394613.139 & 6 & 5 & 6 & 197 & 40 & 118 & 13.1 & 2.8 & 7.9 \\
\hline CIP 399067.22 & 11 & 5 & 8 & 63 & 97 & 80 & 4.3 & 6.5 & 5.4 \\
\hline Lady Rosita (Check) & 7 & - & - & 128 & - & - & 8.6 & - & - \\
\hline Jumli Local (Check) & - & 6 & - & - & 204 & - & - & 15.6 & - \\
\hline F-Test & * & $*$ & & $* *$ & $* *$ & & $* *$ & $* *$ & \\
\hline $\operatorname{LSD}(0.05)$ & 2.1 & 2.0 & & 73.0 & 73.2 & & 4.0 & 4.6 & \\
\hline
\end{tabular}

Total tuber number, marketable tuber weight and yield of potato genotypes in on-farm experiments of Dolakha and Jumla has been shown in Table 2. In Dolakha, the highest number of tuber plant ${ }^{-1}$ was recorded in 'Lady Rosita' (9) followed by CIP 395112.32 (8). But in Jumla, it was recorded the highest (7) in CIP 394611.112 and CIP 395017.242, whereas the lowest (2) in CIP 392740.4. Pooled mean over the locations revealed the highest tuber number (9) in CIP 394611.112 and CIP 395017.229. In Dolakha, CIP 395112.32 yielded the highest ( $422 \mathrm{~g}$ ) marketable tuber weight plant ${ }^{-1}$, but it was highest in CIP $395017.242(465 \mathrm{~g})$ in Jumla. Marketable tuber yield was highly significant $(\mathrm{P} \leq 0.01)$ among the tested clones. Clone CIP 395112.32 gave the highest yield (28.1 Mt.ha $\left.{ }^{-1}\right)$ in Dolakha but in Jumla, clone CIP 395017.242 was the highest $\left(31.0\right.$ tha $\left.^{-1}\right)$ yielder followed by CIP $395017.229\left(28.0\right.$ tha $\left.^{-1}\right)$ and CIP $395113.32\left(24.9\right.$ tha $\left.^{-1}\right)$. The average tuber yield was highest (26.5 tha $\left.^{-1}\right)$ in CIP 395112.32 followed by CIP $395017.229\left(16.6 \mathrm{t} \mathrm{ha}^{-1}\right)$.

Table 2. Total tuber number, marketable tuber weight and yield of potato clones in on-farm experiments in Dolakha and Jumla, 2013

\begin{tabular}{|c|c|c|c|c|c|c|c|c|c|}
\hline \multirow[t]{2}{*}{ Potato clones } & \multicolumn{2}{|c|}{$\begin{array}{l}\text { Total tuber } \\
\text { plant }^{-1} \text { (no.) }\end{array}$} & \multirow[t]{2}{*}{ Mean } & \multicolumn{2}{|c|}{$\begin{array}{l}\text { Marketable tuber } \\
\text { weight plant }^{-1}(\mathrm{~g})\end{array}$} & \multirow[t]{2}{*}{ Mean } & \multicolumn{2}{|c|}{$\begin{array}{l}\text { Marketable tuber } \\
\text { yield }\left(\mathrm{t} \mathrm{ha}^{-1}\right)\end{array}$} & \multirow[t]{2}{*}{ Mean } \\
\hline & Dolakha & Jumla & & Dolakha & Jumla & & Dolakha & Jumla & \\
\hline CIP 395112.32 & 8 & 5 & 7 & 422 & 375 & 399 & 28.1 & 24.9 & 26.5 \\
\hline CIP 393536.13 & 3 & 3 & 3 & 142 & 70 & 106 & 9.3 & 4.7 & 7.0 \\
\hline CIP 392740.4 & 3 & 2 & 3 & 90 & 42 & 66 & 5.8 & 2.9 & 4.4 \\
\hline CIP 393073.179 & 3 & 3 & 3 & 213 & 268 & 240 & 14.2 & 17.8 & 16.0 \\
\hline CIP 399092.116 & 6 & 4 & 5 & 113 & 45 & 79 & 7.5 & 2.9 & 5.2 \\
\hline CIP 393382.44 & 4 & 5 & 5 & 115 & 73 & 94 & 7.5 & 4.7 & 6.1 \\
\hline CIP 394611.112 & 8 & 7 & 8 & 265 & 315 & 290 & 17.6 & 20.9 & 19.3 \\
\hline CIP 390478.9 & 3 & 4 & 4 & 60 & 205 & 132 & 4.1 & 13.6 & 8.9 \\
\hline CIP 393617.1 & 6 & 5 & 6 & 128 & 122 & 125 & 8.6 & 8.2 & 8.4 \\
\hline CIP 399078.11 & 7 & 4 & 6 & 150 & 145 & 148 & 9.8 & 9.7 & 9.8 \\
\hline CIP 395017.242 & 4 & 7 & 6 & 145 & 465 & 305 & 9.6 & 31.0 & 20.3 \\
\hline CIP 395017.229 & 7 & 6 & 7 & 157 & 417 & 287 & 10.4 & 28.0 & 19.2 \\
\hline CIP 394613.139 & 6 & 5 & 6 & 225 & 127 & 176 & 14.8 & 8.4 & 11.6 \\
\hline CIP 399067.22 & 5 & 5 & 5 & 87 & 120 & 104 & 5.9 & 8.0 & 6.9 \\
\hline Lady Rosita (Check) & 9 & - & - & 354 & - & - & 23.6 & - & - \\
\hline Jumli Local (Check) & - & 5 & - & & 40.0 & - & & 2.8 & - \\
\hline F-Test & $*$ & $* *$ & & $* *$ & $* *$ & & $* *$ & $* *$ & \\
\hline $\operatorname{LSD}(0.05)$ & 2.1 & 2.0 & & 123.0 & 125.0 & & 7.0 & 8.2 & \\
\hline
\end{tabular}

Maturity type of potato clones and tuber characters has been shown in Table 3. CIP 390478.9, CIP 394613.139, and CIP 399067.22 were observed as early maturing clones, while rests of the clones were medium to late maturing types. Out of 14 clones tested, six were red-skinned and remaining were white skinned types. Flesh color was varied from yellow to creamy type. Tubers of six clones were yellow fleshed and remaining eight was creamy. Tubers of CIP 395112.32, CIP 393073.179, and CIP 399078.11 had oval shaped tubers, whereas rests were long, oblong, round and round-flat type tubers type. Most of the tested clones were observed shallow eyed tubers (Table 3). Based on mean yield and tuber characters, clones CIP 
395112.32, CIP 395017.229, CIP 394611.112, CIP 395017.242, CIP 393617.1, CIP 399078.11 and CIP 393073.179 were selected from both the places. In addition, CIP 394613.139 and CIP 390478.9 were selected as promising clones from Dolakha and Jumla, respectively.

Table 3. Tuber characters of potato clones tested at on-station and on-farm experiments, 2013

\begin{tabular}{|c|c|c|c|c|c|}
\hline \multirow[t]{2}{*}{ Potato clones } & \multirow[t]{2}{*}{ Maturity $^{Z}$} & \multicolumn{4}{|c|}{ Tuber characters } \\
\hline & & Skin color & Flesh color & Shape & Eye depth \\
\hline CIP 395112.32 & Late & Light red & Yellow & Oval & Shallow \\
\hline CIP 393536.13 & Late & White & Cream & Oval & Medium \\
\hline CIP 392740.4 & Late & Creamy white & Cream & Long oblong & Shallow \\
\hline CIP 393073.179 & Medium & White & Cream & Oval & Shallow \\
\hline CIP 399092.116 & Medium & Red & Yellow & Round & Shallow \\
\hline CIP 393382.44 & Medium & Dark red & Yellow & Round & Deep \\
\hline CIP 394611.112 & Medium & Red & Yellow & Round flat & Medium \\
\hline CIP 390478.9 & Early & White & Cream & Round flat & Shallow \\
\hline CIP 393617.1 & Late & White & Cream & Round & Shallow \\
\hline CIP 399078.11 & Late & Dark red & Yellow & Oval & Deep \\
\hline CIP 395017.242 & Late & White & Cream & Round flat & Shallow \\
\hline CIP 395017.229 & Late & White & Cream & Round & Shallow \\
\hline CIP 394613.139 & Early & Red & Cream & Round & Deep \\
\hline CIP 399067.22 & Early & Light red & Yellow & Long oblong & Shallow \\
\hline Lady Rosita (Check) & Medium & Red & Yellow & Round & Medium \\
\hline Jumli Local (Check) & Medium & White & Cream & Long oblong & Medium \\
\hline
\end{tabular}

${ }^{\mathrm{z}}$ Maturity: Early (<90 days), Medium (90-110 days) and Late (110-130 days) (Khatri and Luitel 2014).

\section{Yield evaluation in experiment II}

Total tuber number, marketable tuber weight and yield of potato genotypes tested in on-stations experiments at both districts are given in Table 4 . Total tuber number plant ${ }^{-1}$ was highly significant $(\mathrm{P} \leq 0.01)$ at both the sites. In Dolakha, the average tuber number was counted the highest in the clone CIP 394611.112 (7) and 'Lady Rosita' (6) but in Jumla, the highest (12) tuber yield was obtained in 'Jumli Local'. Average number of tuber were produced the highest (7) by the CIP 394611.112. Clone CIP 393073.173 produced the highest marketable tuber weight plant ${ }^{-1}$ in Dolakha (291.0 g) and Jumla (413 g) with average of $352 \mathrm{~g}$. Marketable yield was highly significant $(\mathrm{P} \leq 0.01)$ among the clones tested in both the districts. CIP 393073.179 recorded the highest marketable yield (19.4 ${\left.\mathrm{Mt} . h a^{-1}\right)}^{-}$both in Dolakha and Jumla with average yield of $23.5 \mathrm{t}$ ha ${ }^{-1}$.

Table 4. Total tuber number, marketable tuber weight and yield of potato clones in on-station experiments in Dolakha and Jumla, 2014

\begin{tabular}{|c|c|c|c|c|c|c|c|c|c|}
\hline \multirow[t]{2}{*}{ Potato clones } & \multicolumn{2}{|c|}{$\begin{array}{l}\text { Total tuber } \\
\text { plant }^{-1} \text { (no.) }\end{array}$} & \multirow[t]{2}{*}{ Mean } & \multicolumn{2}{|c|}{$\begin{array}{l}\text { Marketable tuber } \\
\text { weightplant }^{-1}(\mathrm{~g})\end{array}$} & \multirow[t]{2}{*}{ Mean } & \multicolumn{2}{|c|}{$\begin{array}{l}\text { Marketable tuber } \\
\text { yield }\left(\mathrm{t} \mathrm{ha}^{-1}\right)\end{array}$} & \multirow[t]{2}{*}{ Mean } \\
\hline & Dolakha & Jumla & & Dolakha & Jumla & & Dolakha & Jumla & \\
\hline CIP 395112.32 & 5 & 5 & 5 & 119 & 332 & 225 & 7.9 & 22.1 & 15.0 \\
\hline CIP 395017.229 & 4 & 4 & 4 & 152 & 233 & 192 & 10.1 & 15.6 & 12.9 \\
\hline CIP 394611.112 & 7 & 6 & 7 & 153 & 313 & 233 & 10.1 & 20.8 & 15.5 \\
\hline CIP 395017.242 & 3 & 4 & 4 & 82 & 210 & 146 & 5.5 & 13.9 & 9.7 \\
\hline CIP 393617.1 & 5 & 5 & 5 & 121 & 227 & 174 & 8.0 & 15.1 & 11.6 \\
\hline CIP 399078.11 & 1 & 4 & 3 & 29 & 144 & 88 & 1.9 & 9.6 & 5.8 \\
\hline CIP 393073.179 & 4 & 5 & 5 & 291 & 413 & 352 & 19.4 & 27.5 & 23.5 \\
\hline CIP 394613.139 & 3 & - & - & 77 & - & - & 5.1 & - & - \\
\hline CIP 390478.9 & - & 5 & - & - & 368 & - & - & 24.6 & - \\
\hline Lady Rosita (Check & 6 & - & - & 196 & - & & 10.3 & - & \\
\hline Jumli Local (Check', & - & 12 & - & - & 264 & - & - & 17.6 & \\
\hline F-Test & $* *$ & $* *$ & & $* *$ & $* *$ & & $* *$ & $* *$ & \\
\hline $\operatorname{LSD}(0.05)$ & 1.7 & 2.2 & & 76.2 & 63.9 & & 4.7 & 4.2 & \\
\hline
\end{tabular}

** indicates significant at $\mathrm{P} \leq 0.01$ level. '-' indicates genotypes are not tested. 
The analyzed data on tuber number, marketable tuber weight and yield of potato clones in on-farm experiments from both the districts is presented in Table 5. Tuber number plant ${ }^{-1}$ was produced highest by the clone CIP 394611.112 (7) in Dolakha but 'Jumli Local' produced the highest (14) in Jumla. Highest (7) average tuber number plant ${ }^{-1}$ were counted in CIP 394611.112. Marketable tuber weight was significant $(\mathrm{P} \leq 0.05)$ among the potato genotypes tested in Dolakha district. Clone CIP 393073.179 yielded the highest marketable tuber weight ( $302 \mathrm{~g})$ and the lowest ( $83 \mathrm{~g}$ ) was in CIP 399078.11. In Jumla, CIP 390478.9 gave the highest $(676.0 \mathrm{~g})$ weight of marketable tuber plant ${ }^{-1}$ followed by CIP $395112.32(574 \mathrm{~g})$. The average marketable tuber weight was highest (412 g) in CIP 395112.32 and the lowest (144 g) in CIP 393617.1. Marketable tuber yield was found highly significant $(\mathrm{P} \leq 0.01)$ among the clones.CIP 393073.179 and CIP 395112.32 produced the highest yield in Dolakha $\left(20.1 \mathrm{tha}^{-1}\right)$ and Jumla $\left(38.3 \mathrm{t} \mathrm{ha}^{-1}\right)$, respectively whereas, the average marketable tuber yield produced the highest $\left(27.5 \mathrm{t} \mathrm{ha}^{-1}\right)$ in CIP 395112.32 .

Table 5. Total tuber number, marketable tuber weight and yield of potato clones in on-farm experiments of Dolakha and Jumla, 2014

\begin{tabular}{|c|c|c|c|c|c|c|c|c|c|}
\hline \multirow[t]{2}{*}{ Potato clones } & \multicolumn{2}{|c|}{$\begin{array}{l}\text { Total tuber } \\
\text { plant }^{-1}(\text { no. })\end{array}$} & \multirow[t]{2}{*}{ Mean } & \multicolumn{2}{|c|}{$\begin{array}{l}\text { Marketable tuber } \\
\text { weight plant }^{-1}(\mathrm{~g})\end{array}$} & \multirow[t]{2}{*}{ Mean } & \multicolumn{2}{|c|}{$\begin{array}{l}\text { Marketable tuber } \\
\text { yield }\left(\mathrm{t} \mathrm{ha}^{-1}\right)\end{array}$} & \multirow[t]{2}{*}{ Mean } \\
\hline & Dolakha & Jumla & & Dolakha & Jumla & & Dolakha & Jumla & \\
\hline CIP 395112.32 & 5 & 7 & 6 & 249 & 574 & 412 & 16.6 & 38.3 & 27.5 \\
\hline CIP 395017.229 & 6 & 4 & 5 & 187 & 184 & 186 & 12.5 & 12.2 & 12.4 \\
\hline CIP 394611.112 & 7 & 7 & 7 & 227 & 416 & 322 & 15.1 & 27.7 & 21.4 \\
\hline CIP 395017.242 & 3 & 5 & 4 & 103 & 246 & 175 & 6.9 & 16.4 & 11.7 \\
\hline CIP 393617.1 & 6 & 5 & 6 & 121 & 166 & 144 & 8.1 & 11.1 & 9.6 \\
\hline CIP 399078.11 & 3 & 5 & 4 & 83 & 240 & 162 & 5.5 & 16.1 & 10.8 \\
\hline CIP 393073.179 & 4 & 4 & 4 & 302 & 462 & 382 & 20.1 & 30.8 & 25.5 \\
\hline CIP 394613.139 & 4 & - & - & 132 & - & - & 8.8 & - & - \\
\hline CIP 390478.9 & - & 9 & - & - & 676 & - & - & 31.3 & - \\
\hline Lady Rosita (Check) & 5 & - & & 213 & - & & 14.2 & - & \\
\hline Jumli Local (Check) & - & 14 & & - & 344 & & & 23.0 & \\
\hline F-Test & $* *$ & $* *$ & & * & $* *$ & & $* *$ & $* *$ & \\
\hline $\operatorname{LSD}(0.05)$ & 1.7 & 2.4 & & 66.9 & 150.8 & & 4.5 & 10.2 & \\
\hline
\end{tabular}

* and ** indicate significant at $\mathrm{P} \leq 0.05$ and $\mathrm{P} \leq 0.01$ level, respectively. '-' indicates genotypes are not tested.

Marketable tuber yield between on-station and on-farm: In Dolakha and Jumla, CIP 393073.179 performed well at onstation followed by CIP 395112.32 (Figure 1A). But in on-farm condition at both locations, CIP 395112.32 exhibited higher yield compared to other tested clones and check varieties 'Lady Rosita' and 'Jumli Local' (Figure 1B). At on-station and onfarm experiment of both the locations, CIP 395112.32 and CIP 393073.179 were found high yielding potato clones.
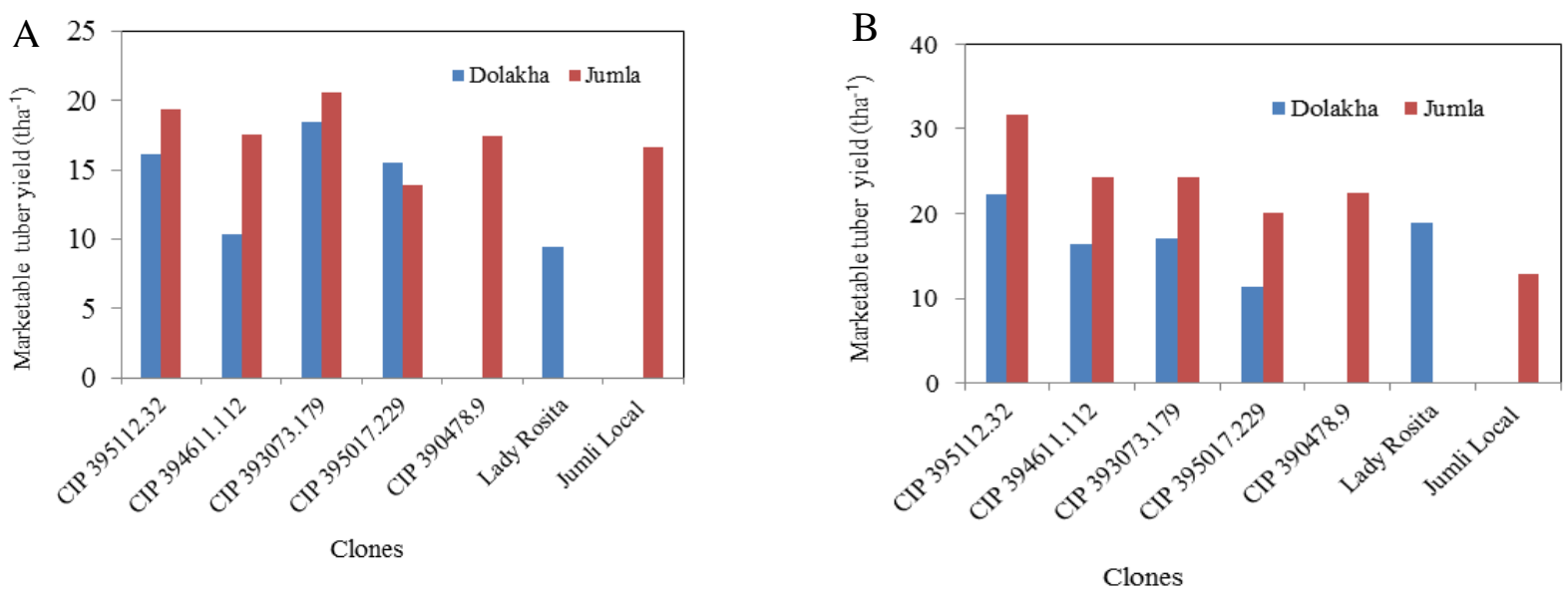

Figure 1. Average marketable tuber yield $\left(\mathrm{t} \mathrm{ha}^{-1}\right)$ of promisıng potato cıones. A, on-statıons (עoıakna ana Jumıa), ana $\mathbf{b}$, on-Iarms (Dolakha and Jumla) during 2013-2014. 
In Dolakha, CIP 395112.32 and CIP 393073.179 had 5.1 and $3.7 \mathrm{t} \mathrm{ha}^{-1}$ of yield difference with 'Lady Rosita', respectively (data not shown), whereas yield increment of both genotypes over 'Lady Rosita' was 35.9 and $25.4 \%$, respectively (Table 6). CIP 394611.112 and CIP 395017.229 exhibited negative yield difference $\left(-0.8\right.$ and $\left.-0.7 \mathrm{t} \mathrm{ha}^{-1}\right)$ with 'Lady Rosita' indicating the inferiority over check variety (data not shown). In Jumla, CIP 395112.32, CIP 393073.179, CIP 394611.112, CIP 390478.9 and CIP 395017.229 exhibited the yield difference of 10.7, 7.7, 6.2, 5.2 and $2.3 \mathrm{t}^{-1}{ }^{-1}$ with 'Jumli Local' (data not shown). In this result, yield increment of CIP 390478.9 was by $37.2 \%$ over 'Jumli Local' and this genotype performed well only in Jumla.

Table 6. Average yield and yield increment of promising potato clones over 'Lady Rosita' and 'Jumli Local' in two sites (Dolakha and Jumla) during 2013 and 2014 (means of the two years).

\begin{tabular}{|c|c|c|c|c|c|c|c|c|}
\hline Sites & Variables & CIP39511 & CIP394611.11: & CIP393073.17! & CIP395017.22! & CIP390478.9 & $\begin{array}{l}\text { Lady } \\
\text { Rosita }\end{array}$ & $\begin{array}{l}\text { Jumli } \\
\text { Local }\end{array}$ \\
\hline \multirow[t]{2}{*}{ Dolakha } & Average yield $\left(\mathrm{t} \mathrm{ha}^{-1}\right)$ & 19.3 & 13.3 & 17.8 & 13.4 & - & 14.2 & - \\
\hline & Yield increment (\%) & 35.9 & -6.3 & 25.4 & -5.6 & - & - & - \\
\hline \multirow[t]{2}{*}{ Jumla } & Average yield(t ha $\left.{ }^{-1}\right)$ & 25.5 & 20.9 & 22.5 & 17.0 & 19.9 & - & 14.5 \\
\hline & Yield increment (\%) & 75.9 & 44.1 & 55.2 & 17.2 & 37.2 & - & - \\
\hline
\end{tabular}

'-' indicates genotypes are not tested.

\section{DISCUSSION}

This study evaluated the nutrient-rich potato clones at high hills districts: Dolakha and Jumla of Nepal which represents the central and mid-western region of Nepal, respectively. Potato is very important crop for food and nutritional security in these regions (Luitel et al 2016b). New potato varieties can be developed from different approaches but NPRP has followed the method of testing and evaluation of advanced clones bred by CIP, Peru (PRP 2000). Generally, popular cultivars are difficult to be replaced but cultivar development is continuous process (Struik and Wiersema 1999). Cultivar characters affect not only yield but also production costs, environmental issues (eg requirement of pesticides), postharvest losses and yield of future crops. The on-station and on-farm experiments in both the years revealed that genotypes showed significantly different in total tuber plant ${ }^{-1}$, marketable tuber weight plant $^{-1}$ and marketable tuber yield in Dolakha and Jumla. Tuber yield is a complex trait that is influenced by many factors. It is mainly affected by environmental factors and cultivar (Struik and Wiersema 1999). The environmental factors including soil temperature, moisture, light intensity, nutrient supply and proper control of disease and pests affect the tuber yield (Struik and Wiersema 1999). The significant $(\mathrm{P} \leq 0.05)$ variation in tuber plant $^{-1}$, tuber weight plant ${ }^{-1}$ and marketable tuber yield observed within the location might have been due to genotypic or varietal factor. And similar results were reported by previous studies (Hassanpanah et al 2011, Kumar et al 2008, Marwaha et al 2007). High tuber yield may be due to good plant emergence and better plant growth but this study lacks the vegetative data to explain it. It may also be associated with higher number of tuber plant ${ }^{-1}$ (Mehdi et al 2008, Patel et al 2008). Besides, long growing period or crop maturity period affects the yield of potato varieties (Wang et al 1995). A significant variation observed in marketable yield at on-station and on-farm trials indicated that same genotype performed differently in different environment and the similar observation of genotype-environment interaction was also reported by Belicka and Bleidere (2005).

In Dolakha, 'Lady Rosita' is well-adaptive variety (personal observation). It is a red-skinned, round shaped tuber but wart susceptible (Luitel et al 2016a). The average yield of 'Lady Rosita' is $13.0 \mathrm{t} \mathrm{ha}^{-1}$ (NPRP 2014) but in the present study, it exhibited high yield in on-farm condition (Table 2). In contrast, 'Jumli Local' is a white skinned, oblong shaped with predominantly small-sized tuber and low yielding variety (personal observation) but in this study, it performed better in onfarm than on-station (Table 5). The CIP 395112.32 is a late variety with high tuber number plant ${ }^{-1}$ and tuber weight plant ${ }^{-1}$ which might contribute to high yield at both locations. Most of the clones exhibited better yield in on-farm experiment compared to on-station. Yield gaps between on-station and on-farm may result from environmental differences, set of biological and socioeconomic condition (Crissman et al 1991). Jumla is more dry than Dolakha and CIP 390478.9 was selected under the dry conditions of Southern Peru, and was released as variety 'Tacna' in Peru. This variety is insensible to photoperiod and tolerant to drought and it was also released in China under the name of 'Jizhangshu 8' and is now widely cultivated in drought-prone areas (CIP 2010). CIP 390478.9 yielded well in dry conditions (Carli et al 2014) and in our study in Jumla, it also gave better yield indicating that this genotype could be appropriate in Jumla. 
Qualitative characters such as skin and flesh color, and eye depth are stable over the environments and therefore, tuber characters of studied potato genotypes at two locations did not change. In contrast, maturity class, tuber number and yield are influenced by environment (Struik and Wiersema 1999). On the other hand, tuber shape, skin and flesh color, eye depth and general appearance are the distinctive quality parameters that influence consumer's choice (Pandey et al 2000). Besides, tuber round to oblong in shape are suitable for chip making and long oval to very long oval shaped tubers are best for making French fries (Pandey et al 2008). In general, consumers prefer potatoes having shallow to medium eye depth (Kabira and Lemaga 2006). CIP 395112.32 is resistant to late blight and acceptable rank of tuber appearance, taste and texture in Dolakha region (Luitel et al 2016a). Likewise, CIP 393073.179, CIP 395112.32 and CIP 394611.112 exhibited acceptable quality for appearance, taste and texture (Luitel et al 2016b).

\section{CONCLUSION}

The results clearly indicated the superiority of some introduced clones over the local varieties at the both the sites. CIP 395112.32 and CIP 393073.179 performed better both at on-station and on-farm trials in both the regions compared to local varieties. In Dolakha, two clones namely CIP 395112.32 and CIP 393073.179 showed superior yield over 'Lady Rosita' while in Jumla, CIP 395112.32, CIP 393073.179, CIP 394611.112, CIP 390478.9 and CIP 395017.229 exhibited higher marketable tuber yield than 'Jumli Local'. Therefore, CIP 395112.32 and CIP 393073.179 are selected as promising varieties at both Dolakha and Jumla regions whereas CIP 394611.112, CIP 390478.9 and CIP 395017.229 are recommended for further testing in Jumla district.

\section{ACKNOWLEDGEMENT}

The authors would like to thank CIP/ADA (Austria Development Agency) for providing the financial support from the project 'Improving food security and nutrition of rural people in Nepal and Bhutan through collaborative potato breeding for yield stability and micronutrient density' during 2012/13 - 2014/15. Thanks to all staffs of NSPC Nigaley and ARS, Rajikot and associated farmers of and farmers of Dolakha and Patmara and Talium village of Jumla for their cooperation during experimentation.

\section{REFERENCES}

ABPSD. 2013. Agribusiness Promotion and Statistical Division. Ministry of Agricultural Development. Singh Durbar, Kathmandu.

Assefa T, G Abebe, C Fininsa, B Tesso and AR Al-Tawaha. 2005. Participatory bean breeding with women and samll holder farmers in eastern Ethiopia. World Journal of Agricultural Sciences 1:28-35.

Bleicka I and M Bleidere. 2005. Variety testing for organic farming: Current status and problems in Europe. In: Seminar on ' Environment friendly food production system: Requirement for plant breeding and seed production' $6^{\text {th }}$ Framework Program FP-2003-SSA-1007003 , p.35.

Carli C, F Yuldashev, D Khalikov, B Condori, V Mares and P Monneveux. 2014. Effect of different irrrigation regimes on yield, water use efficiency and quality of potato (Solanum tuberosum L.) in the lowlands of Tashkent, Uzbekistan: A field and modeling perspective. Field Crops Research 163: 90-99.

CIP. 2010. Focus on Partnerships: Enriching the Science, Expanding the Reach, Enhancing the impact. International Potato Center Annual Report 2009. International Potato Center, Lima Peru.

CIP. 2014. Catalogue of CIP Advanced Clones. International Potato Center, Lima, Peru.

Crissman CC, RE Bedey, MF Sabaa and MF Sharaf. 1991. Agronomic evaluation of different types of potato planting material in Egypt. International Potato Center (CIP), Lima, Peru. Working Paper. p 10.

De Haan S, A Forbes, W Amoros, M Gastelo, E Salas, V Hualla, F De Mendiburu and M Bonierbale 2014. Procedure for standard evaluation and data management of advanced potato clones. Module 2. Healthy tuber yield trials. International Cooperators' Guide. Lima (Peru). International Potato Center. 14p.

Hassanpanah D, H Hassanabadi and SH Azizi Chakherchaman. 2011. Evaluation of cooking quality characteristics of advanced clones and potato cultivars. American Journal of Food Technology 6:72-79.

Kabira JN and B Lemaga. 2006. Potato processing: Quality evaluation procedures for research and food industries applications in East and Central Africa. Kenya Agricultural Research Publication, Nairobi, Kenya.

Khatri BB and BP Luitel. 2014. Field book for standard evaluation of potato and sweet potato germplasm. Government of Nepal, Nepal Agricultural Research Council (NARC), National Potato Research Programme, Khumaltar, Lalitpur, Nepal.

Khatri BB, BP Luitel and D Chaudhary, 2015. Released and registered potato varieties so far in Nepal: a brief introduction. Government of Nepal, Nepal Agricultural Research Council, National Potato Research Program, Khumaltar, Lalitpur, Nepal. pp.1-16 (In Nepali). 
Khatri BB, BP Luitel, D Chaudhary, BP Sharma, J Ghimire, BM Sakha, SP Dhital and GP Rai. 2010. IPY-8 and KhumalLaxmi: Newly Released Potato Varieties. Nepalese Horticulture 7:29-37.

Kumar R, GS Kang and SK Pandey. 2008. Estimation of genetic parameters and combining ability for characters related to potato propagation by true potato seed. Potato Journal 35 (1):12-18.

Luitel BP, BB Khatri, D Choudhary, MS Kadian, S Arya and M Bonierbale. 2016a. Evaluation of advanced potato clones for plant and yield characters at high hills of Nepal. Potato Journal 43 (2):118-124.

Luitel BP, L Lama, BB Khatri, D Choudhary, RK Giri, MS Kadian, S Arya, R Dhakal and M Bonierbale. 2016b. Evaluation of micro-nutrient rich potato genotypes in temperate conditions of Nepal. Potato Journal 43 (2):138-145.

Marwaha RS, SK Pandey, SV Singh and D Kumar. 2007. Yield, chipping and nutritive qualities of spring grown potatoes in north western plains. Potato Journal 34 (1-2): 61-62.

Mehdi M, T Saleem, HK Rai, MS Mir and G Rai. 2008. Effect of nitrogen and FYM interaction on yield and yield traits of potato genotypes under Ladakh condition. Potato Journal 35 (3-4):126-129.

NPC. 2010. The food security atlas of Nepal. Food Security Monitoring Task Force, National Planning Commission, Government of Nepal

NPRP. 2014. Annual Report 2013. National Potato Research Program, NARC, Khumaltar, Lalitpur

Pandey SK, GS Shekhwat and D Sarkar. 2000. Quality attributes of Indian potatoes for export: priorities and possibilities. Journal of Indian Potato Association 27(3-4):103-111.

Pandey SK, SV Singh, D Kunar, P Manivel, RS Marwaha, P Kumar, BP Singh and VK Gupta. 2008. Kufri chipsona: a chipping cultivar for hill regions of India. Potato Journal 35 (1-2): 1-8.

Patel CK, PT Patel and SM Chaudhari. 2008. Effect of physiological age and seed size on seed production of potato in North Gujarat. India. Potato Journal 36 (2-3):18-23.

PRP, 2000. Annual Report 1999. Potato Research Program, NARC, Khumaltar, Lalitpur, Nepal.

Romney DL, P Thorne, B Lukuyu and PK Thornton. 2003. Maize as food and feed in intensive smallhoder systems: management options for improved integration in mixed farming systems of east and southern Africa, Field Crops Research 84:159-168.

Struik PC and SG Wiersema. 1999. Seed potato technology. Wageningen Pers, Wageningen. p.51.

Wang R, L Lihua, H Liu and RG Wang. 1995. Present state of research on potato germplasm resources in China. Crop Genetic Resources 3:20-22. 